\title{
Level Decreasing Kinetics Model of Heavy Metal Contents in The Coal Stockpile Wastewater with Electrocoagulation
}

\author{
Rusdianasari $^{\# 1}$, Anerasari Meidinariasty ${ }^{\# 2}$ and Indah Purnamasari ${ }^{\# 3}$ \\ * Chemical Engineering Department, State Polytechnic of Sriwijaya, Palembang 30139, Indonesia \\ E-mail: ${ }^{1}$ rusdianasari19@gmail.com; ${ }^{2}$ anerasari@yahoo.com; ${ }^{3}$ indah_chemistry@yahoo.com
}

\begin{abstract}
Electrocoagulation is one of methods used to treat wastewater in the coal stockpile without using coagulants. Characteristics of wastewater observed are heavy metals (Fe and Mn) and pH. The decrease in the heavy metals content and the increase in the $\mathrm{pH}$ of this wastewater treatment process will then be proposed in the adsorption kinetics model. The influence of variations in currents and processing time were observed. The time variation of the adsorption process were 60 to 120 minutes with current variations from 1.3 to 3.0 Ampere at a fixed 12 voltages. The results obtained that the Fe content could be decreased to 0.03 ppm at 90 minutes while the content of $\mathrm{Mn}$ was decreased to $0.01 \mathrm{ppm}$ at the same time. The increase in pH (7.11) was achieved when applying 2.5 A current at 90 minutes process time. The results obtained from the electrocoagulation method was then proposed in the model of the Langmuir isotherm adsorption kinetics and Freundlich isotherm.
\end{abstract}

Keywords - electrocoagulation; coal stockpile; heavy metals; adsorption kinetics

\section{INTRODUCTION}

Electrocoagulation technique is an electrochemical technology for the treatment of water and wastewater uses an electrochemical cell, where a DC voltage is applied to the electrodes corroded to generate a coagulant, and the electrolyte is usually water effluents. Electrocoagulation is an efficient treatment process for various type of wastes such as soluble oil, liquid from food, textile industries, cellulose and effluents from paper industry [1].

Electrocoagulation process has been successfully employed for colouring, heavy metals and COD removal of industrial wastewater [2]. The electrocoagulation technique has several advantages including the ability to deliver a precise coagulant dose via control of the amount of applied electrical current, easy automation, low energy requirement, and the ability to destabilize, aggregate, and separate the pollutant in a single state [3,4].

The pollutant is generally adsorbed at the surface of the flocks (coagulant) generated electrochemically. Critical analysis of the electrocoagulation of pollutants reveals that there are two separate processes taking place, i.e. $[5,6]$ :

- Electrochemical process through which the metal flocks are generated

- Physio-chemical process through which the effluent are adsorbed on the surface of the flocks.
The removal of pollutant is similar to conventional adsorption except the generation of coagulants. The electrode consumption can be estimated according to Faraday's Law and the amount of flocks generated can be estimated stoichiometrically. Since the amount of coagulant can be modelled by adsorption phenomenon. During electrocoagulation the insoluble metal hydroxides removes pollutants by surface adsorption [7].

In the adsorption it is assumed that the pollutant can act as a liquid to bind a hydrous iron/Al in situ formed gelatinous precipitate, it is further attempted to extend the adsorption isotherm models for pollutant removal by Langmuir, Freundlich and Temkin models $[7,8,9,10]$.

The Langmuir isotherm assumes monolayer deposition of adsorbent surface (coagulant). It is well known that the Langmuir equation is intended for a homogeneous surface.

The Freundlich isotherm is an empirical model relating the adsorption intensity of the sorbent towards adsorbent. The isotherm is adopted to describes reversible sorption and not restricted to monolayer formation. The Temkin isotherm describes the behaviour of adsorption system on heterogeneous surface. To aim of this study was to determine the performance of electrocoagulation process in heavy metals removal and to predict a well fit mathematic models that describe the kinetics heavy metals removal from coal stockpile wastewater by means of electrocoagulation technique with various operating condition. 


\section{EXPERIMENTAL}

A laboratory scale electrochemical set up made up of glass beaker cell, electrodes and other accessories were arranged as in (Fig. 1). However, in each run, 1 litre of sample was used to treat by electrocoagulation process. Two electrodes of aluminum with surface area of $40 \mathrm{~cm}^{2}$. The separation between the anode and the cathode was kept 10 $\mathrm{cm}$ [11]. The solution in the reactor was stirred by a magnetic stirrer at rotating velocity of $100 \mathrm{rpm}$. Controlled direct current was supplied by a DC power supply. The current was kept invariant in each test by a rheostat and measured by an ammeter. The effect of coal stockpile wastewater heavy metals removal efficiencies were studied with different current densities. The electrical potential was held constant for each run, being at 12 volts. The calculation of $\mathrm{Fe}$ and $\mathrm{Mn}$ removal efficiencies after electrocoagulation treatment were performed using the following formula [12]:

$$
\mathrm{C}_{\mathrm{R}}(\%)=[(\mathrm{Co}-\mathrm{C} / \mathrm{Co}] \times 100
$$

Where $C_{R}$ is contaminant removal, $C o$ and $C$ are concentrations of wastewater before and after electrocoagulation.

Several electrocoagulation batch experimental runs were performed in the laboratory. Initially wastewater was rigorously stirred for 10 minutes by stirrer for homogenization of sample. Then a specific current density was applied for various time periods (ranging from 60 minutes to 120 minutes). Treated wastewater samples were collected after settling for predetermined time to estimate the effect of electrocoagulation treatment time on removal efficiency heavy metals ( $\mathrm{Fe}$ and $\mathrm{Mn}$ ). The sample was allowed to settle for 60 minutes after treatment so that the flocks (coagulates) that were formed during electrocoagulation may settle. In each experimental run, after settling, about $50 \mathrm{~mL}$ supernatant sample was collected for laboratory analysis.

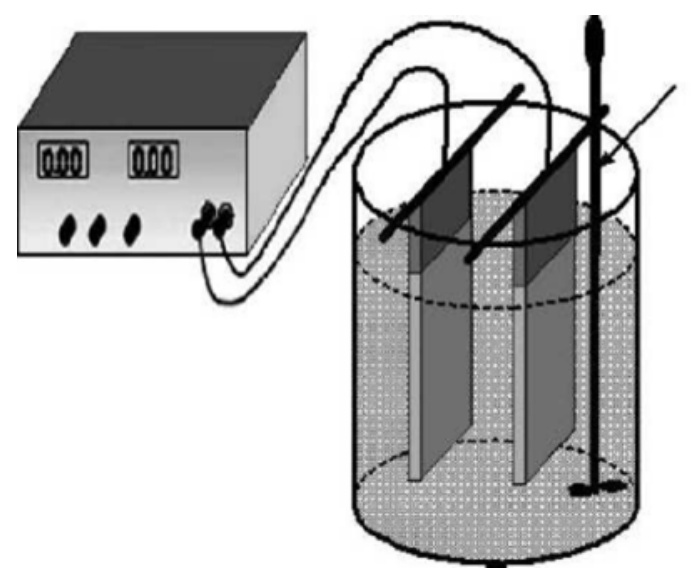

Fig. 1 Scheme of experimental set

\section{RESULTS AND DISCUSSION}

All experiments were carried out under potentiostatic condition covering a range of electrocoagulation process time of 60 to 120 minutes with current density variations from 1.3 to 3.0 Ampere at a fixed 12 voltages.

\section{A. Effect of Current Density and Process Time to Degradation Content of Fe and $\mathrm{Mn}$}

Degradation of $\mathrm{Fe}$ and $\mathrm{Mn}$ content on current and process time variations are shown in Fig. 1 and Fig 2. Fig. 1 shown that the percentage of degradation Fe content rose as the current and process time increased. The best results on degradation of Fe metal concentration was at $2.5 \mathrm{~A}$ and 90 minutes process time and reached the equilibrium in 120 minutes. The graphic also shown the degradation ranged from $0.08 \mathrm{ppm}-0.03 \mathrm{ppm}$.

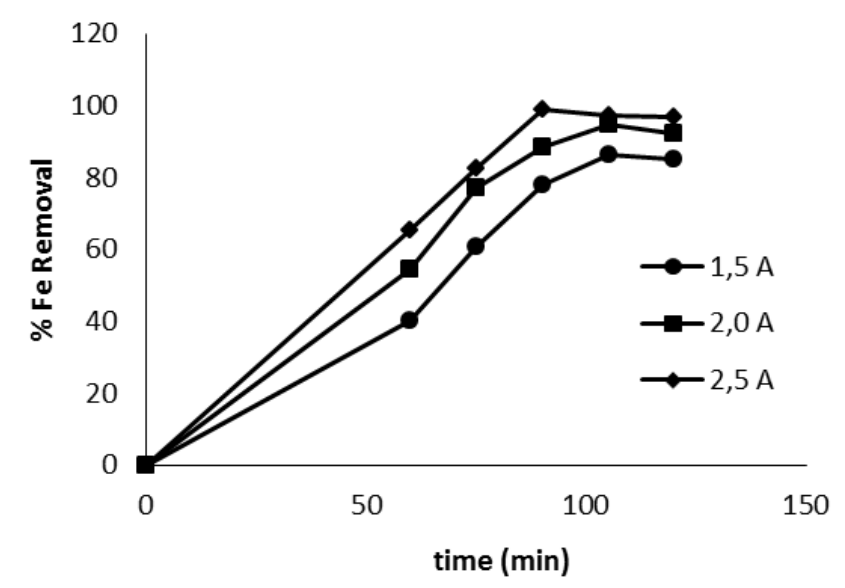

Fig. 2 . Decreased percentage of Fe content by electrocoagulation current and process time variations

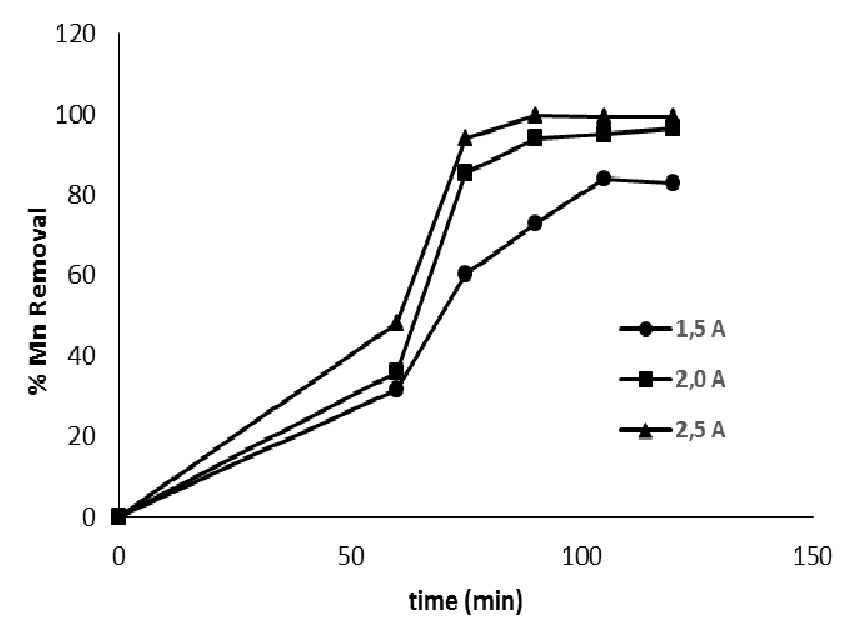

Fig. 3 . Decreased percentage of Mn content by electrocoagulation current and process time variations

Fig. 3 shown that by using electrocoagulation method, Mn content had been decreased in coal stockpile wastewater. The dereased of Mn concentration can be up to $99 \%$. The longer the process time the greater the decreased of $\mathrm{Mn}$ metal concentration.

\section{B. Kinetic Model}

Kinetics study of reduced levels of $\mathrm{Fe}$ and $\mathrm{Mn}$ contents proposed three models, namely: model of pseudo first order reaction kinetics, Langmuir isotherm of adsorption kinetics, and Freundlich isotherm of adsorption kinetics. 


\section{First order pseudo kinetic model}

First order reactions is a reaction in which the rate depends on reactan concentration that is exponentially by number 1 . Generally, first order reaction can be represented by this equation:

$$
\mathrm{V}=\mathrm{k}\left(\mathrm{q}_{\mathrm{o}}-\mathrm{q}_{\mathrm{t}}\right) \text { or } \mathrm{V}=\frac{d x}{d t}=\mathrm{k}\left(\mathrm{q}_{\mathrm{o}}-\mathrm{q}_{\mathrm{t}}\right)
$$

Integral of the equation create equal:

$$
\ln \left(\mathrm{q}_{\mathrm{s}}-\mathrm{q}_{\mathrm{t}}\right)=-\mathrm{kt}+\operatorname{In} \mathrm{q}_{\mathrm{s}}
$$

Where $\mathrm{q}_{\mathrm{s}}$ is the adsorbate concentration initially $\left(\mathrm{mg} \mathrm{L}^{-1}\right)$, $\mathrm{q}_{\mathrm{t}}$ is adsorbate concentration adsorbed at time $\mathrm{t}\left(\mathrm{mg} \mathrm{L}^{-1}\right)$ and $\mathrm{k}$ represent first order reaction constant and $\mathrm{t}$ is reaction time (minute). The linear curve can be drawn from In $\left(\mathrm{q}_{\mathrm{s}}-\mathrm{q}_{\mathrm{t}}\right)$ versus t. This first order kinetic models can be seen in Fig. 4 and Fig. 5.

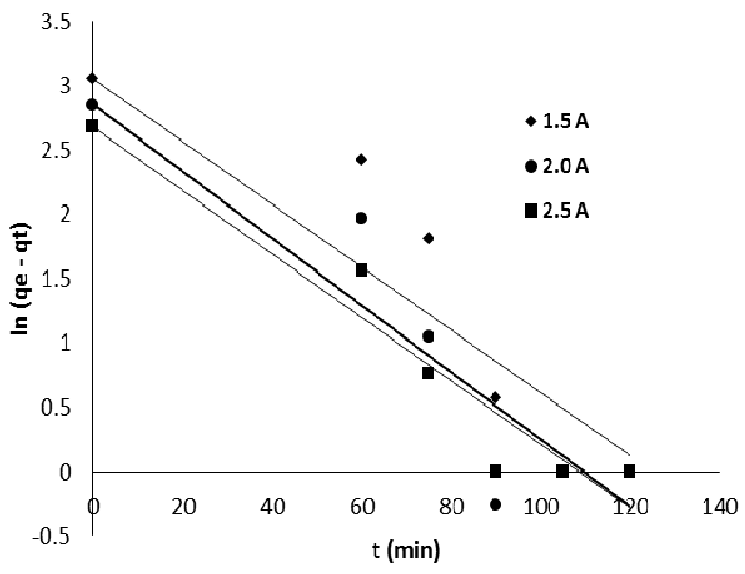

Fig. 4. First order modelling of Fe electrocoagulation

The value to first order adsorption rate constants for each current density are as follow:

\section{TABLE I}

Kinetics MOdel VALUES FOR ADSORPTION FE ONTO ALUMinA COAGULANT

\begin{tabular}{|c|c|c|c|}
\hline Current (A) & $\mathbf{K}_{\mathbf{1}}$ & $\mathbf{q e}$ & $\mathbf{R}^{\mathbf{2}}$ \\
\hline $1.5 \mathrm{~A}$ & 0.0244 & 21.29383 & 0.8391 \\
\hline $2.0 \mathrm{~A}$ & 0.0260 & 17.33333 & 0.8539 \\
\hline $2.5 \mathrm{~A}$ & 0.0247 & 14.56593 & 0.9284 \\
\hline
\end{tabular}

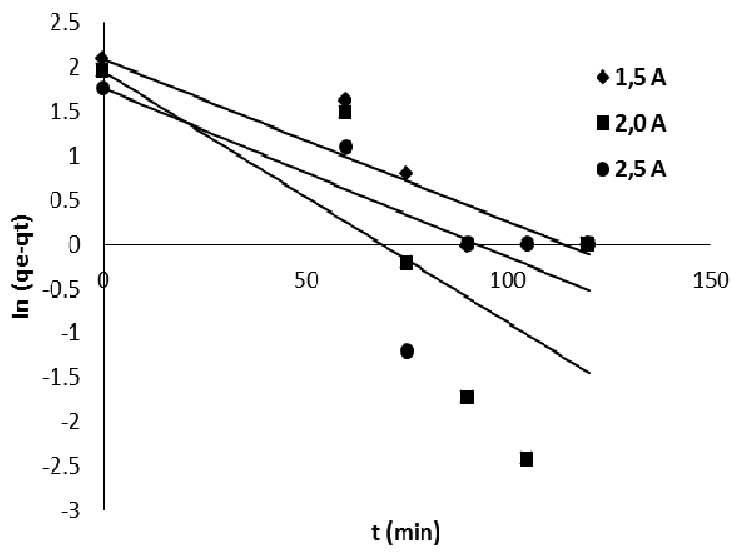

Fig.5. First order modelling of Mn electrocoagulation
And the value for kinetic models are as follow:

TABLE II

Kinetics Model VALUES FOR AdSORPTION MN ONTO ALUMina COAGULANT

\begin{tabular}{|c|c|c|c|}
\hline Current (A) & $\mathrm{K}_{1}$ & $\mathrm{qe}$ & $\mathrm{R}^{2}$ \\
\hline $1.5 \mathrm{~A}$ & 0.0184 & 8.098765 & 0.8501 \\
\hline $2.0 \mathrm{~A}$ & 0.0284 & 7.051852 & 0.5364 \\
\hline $2.5 \mathrm{~A}$ & 0.0191 & 5.807407 & 0.4444 \\
\hline
\end{tabular}

Fig. 4 and Fig. 5 yielded $\mathrm{R}^{2}$ values (regression coefficient) that stated the pseudo first order kinetic model is not suitable for $\mathrm{Fe}$ and $\mathrm{Mn}$ adsorption by mean of electrocoagulation.

\section{Langmuir isotherm adsorption model}

The liquid solid system of Langmuir isotherm adsorption equation is based on adsorption process equilibrium and desorption of adsorbate on the solid surface. The Langmuir equation model is stated as follows:

$$
\mathrm{q}_{\mathrm{c}}=\frac{Q b C \mathrm{~s}}{1+b C_{\mathrm{s}}}
$$

The linear form is:

$$
\frac{C a}{q a}=\frac{1}{Q b}+\frac{C e}{q}
$$

Where $\mathrm{q}_{\mathrm{e}}$ is the amount of adsorbate adsorbed per mass unit adsorbent $\left(\mathrm{mg} \mathrm{g}^{-1}\right)$, Ce is concentration of the adsorbate in equilibrium state $\left(\mathrm{mg} \mathrm{L}^{-1}\right)$, while $\mathrm{Q}$ and $\mathrm{b}$ are Langmuir constant. The value of $\mathrm{Q}$ and $\mathrm{b}$ can be obtained from the intercept and slope of $\mathrm{Ce} \mathrm{q}^{-1}$ versus Ce. Langmuir isotherm adsorption kinetics can be seen in Fig. 6 and Fig. 7, the constant values and $\mathrm{R}^{2}$ can be seen Table 3 and Table 4 .

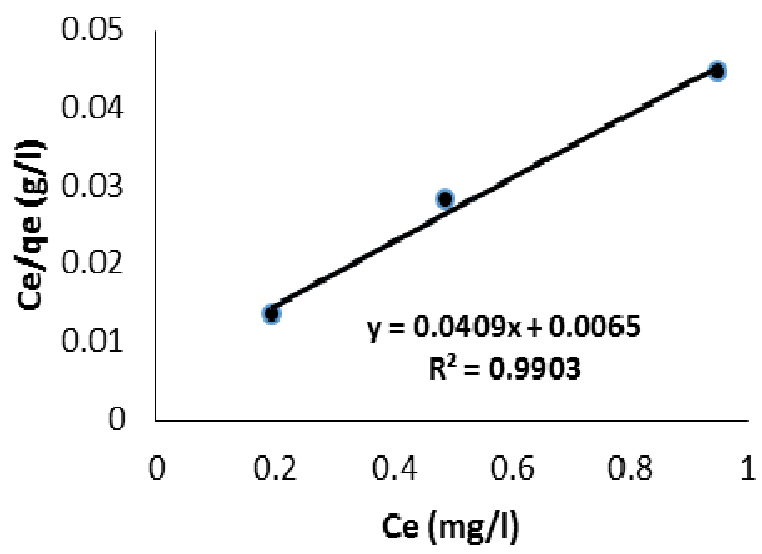

Fig. 6. Langmuir Fe - Adsorption Isotherm

TABLE III

LANGMUIR ISOTHERM CONSTANTS FOR FE ADSORPTION

\begin{tabular}{|c|c|l|}
\hline $\mathrm{R}^{2}$ & Constants & Value \\
\hline 0.9903 & $\mathrm{Q}$ & 24.44988 \\
\hline & $\mathrm{B}$ & 6.292308 \\
\hline
\end{tabular}


TABLE IV

LANGMUIR ISOTHERM CONSTANTS FOR MN ADSORPTION

\begin{tabular}{|c|c|c|}
\hline $\mathrm{R}^{2}$ & constants & Value \\
\hline 0.9997 & $\mathrm{Q}$ & 8.319468 \\
\hline & $\mathrm{B}$ & 85.85714 \\
\hline
\end{tabular}

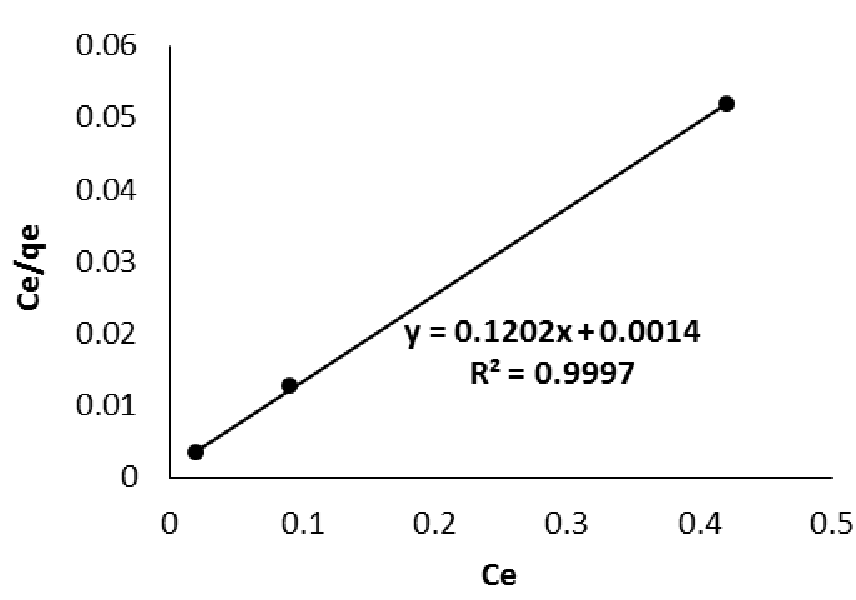

Fig. 7 Langmuir Mn - Adsorption Isotherm

Based on the results obtained from graph between Ce/qe versus Ce, Langmuir isotherm is best adsorption kinetic compared to others. The regression coefficient closer to 1 means that the kinetic model is fit to the experiment data produced.

\section{E. Freundlich isotherm of adsorption kinetic}

Freundlich isotherm is used to model the kinetics of adsorption on heterogeneous adsorbent surface. The linear form of Freundlich equation is as follows:

$$
\mathrm{q}_{\mathrm{e}}=\mathrm{K}_{\mathrm{F}} \mathrm{C}^{1 / \mathrm{n}}
$$

where $\mathrm{K}_{\mathrm{F}}$ and $\mathrm{n}$ are Freundlich constants. Linear form of Freundlich equation is stated in the equation:

$$
\ln \mathrm{q}_{\mathrm{e}}=\ln \mathrm{K}_{\mathrm{F}}+\frac{i}{n} \ln \mathrm{C}_{\mathrm{e}}
$$

$\mathrm{K}_{\mathrm{F}}$ and $\mathrm{n}$ constants is the adsorption capacity and adsorption intensity. $\mathrm{K}_{\mathrm{F}}$ and $\mathrm{n}$ values obtained from the intercept and slope of the plot graph between $\log \mathrm{q}_{\mathrm{e}}$ versus $\log \mathrm{C}_{\mathrm{e}}$.

Based on the plot of $\ln$ qe vs $\ln \mathrm{Ce}$ which is obtained a straight line with a slope $1 / \mathrm{n}$ and intercept $\ln$ Kf. Freundlich plot line for the adsorption $\mathrm{Fe}$ and $\mathrm{Mn}$ are shown in Fig. 8 and Fig. 9 and the result of straight-line plot are presented in Table 5 and Table 6. From the resulting figure shows the adsorption intensity value $1 / \mathrm{n}<1$, it can be said adsorption isotherm enough Freundlich good for adsorption kinetics proposed. However, when compared with the results obtained from the regression constant, kinetic the model Langmuir adsorption isotherm is much better and greater than Freundlich isotherms adsoption.

TABLE V

FREUNDLICH ISOTHERM ADSORPTION CONSTANTS FOR FE

\begin{tabular}{|c|c|c|}
\hline $\mathrm{R}^{2}$ & Constants & Value \\
\hline 0.9798 & $\mathrm{n}$ & 4.226543 \\
\hline & $\mathrm{Kf}$ & 21.1206 \\
\hline
\end{tabular}

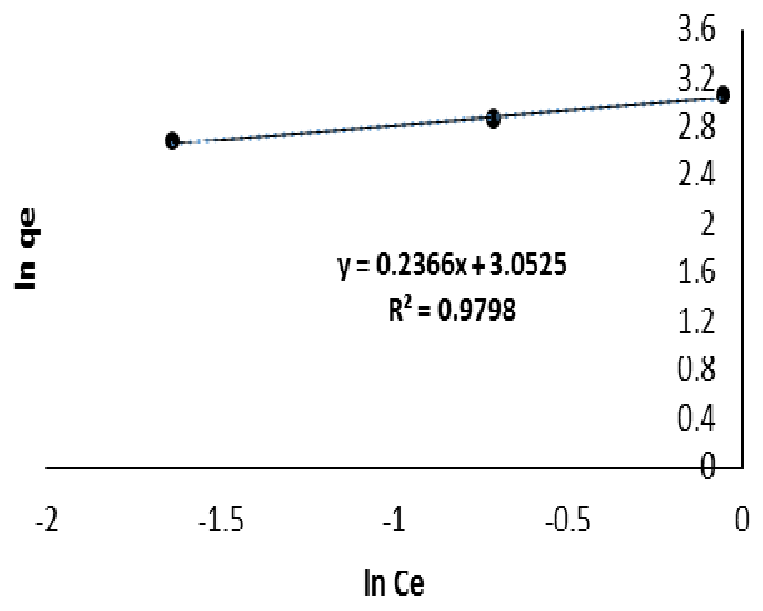

Fig. 8. Freundlich $\mathrm{Fe}-$ Adsorption Isotherm

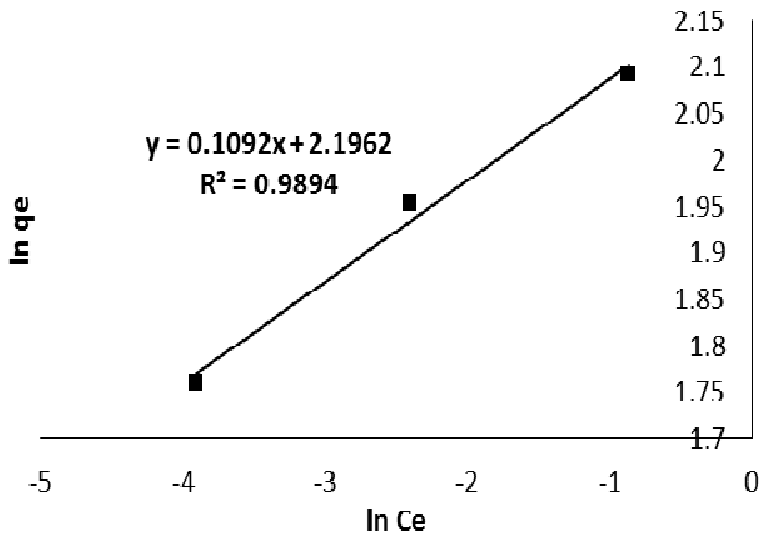

Fig. 9. Freundlich Mn - Adsorption Isotherm

TABLE VI

FREUNDLICH ISOTHERM ADSORPTION CONSTANTS FOR MN

\begin{tabular}{|c|c|c|}
\hline $\mathrm{R}^{2}$ & constants & Value \\
\hline 0.9894 & $\mathrm{n}$ & 9.157509 \\
\hline & $\mathrm{Kf}$ & 8.9909 \\
\hline
\end{tabular}

\section{CONCLUSIONS}

In electrocoagulation of effluent coal stockpile wastewater, the percentage $\mathrm{Fe}$ and $\mathrm{Mn}$ removal is influenced by the applied current density and process time. The percentage heavy metals removal increase with an increase in the applied current density and process time for aluminum electrode. The electrocoagulation process was modeled using adsorption isotherm kinetic and it has been observed from the present investigation that Langmuir isotherm model match satisfactorily with the experimental results.

\section{ACKNOWLEDGMENT}

We thank to the Research and Community Service of Directorate General of High Education for financially supporting this research trough Fundamental Grant Research Program of Budget Year 2015. 


\section{REFERENCES}

[1] Calvo, L.S., et al., "An Electrocoagulation Unit for the Purification of Soluble Oil Waste of High COD”, Environmental Progress, 22(1). 57-65. 2003.

[2] Lin S., and Wu, C., "Electrochemical Removal of Nitrite and Ammonia for Aquaculture". Water Res. 30. 715-721. 1996.

[3] Mollah, et al., "Fundamentals Present and Future Perspective of Electrocoagulation”. J. of Hazard. Matter. B114. 199-210. 2004.

[4] Can, et al., "Treatment of the Textile Wastewater by Combned Electrocoagulation". Chemosphere 62. 181-187. 2006.

[5] Balasubramanian, N., Kojima, T., Srinivasakannan, C. "Arsenic Removal through Electrocoagulation: Kinetics and Statistical Modeling”. Chem. Eng. J. 155. 76-82. 2009.

[6] Ghanim, A.N and Ajjam, S.K. " Modeling of Textile Wasrewater Electrocagulation via Adsorption Isoterm Kinetics". The Iraqi Journal for Mechanical and Material Engineering. Vol. 13 No. 1. 2013.
[7] K. Chithra and N. Balasubramanian. "Modeling Electrocoagulation Adsorption Kinetics". J. of Modeling and Simulation of Systems. Vol. 1 Iss 2. 2010.

[8] Kumar, P.S., Ramakrishnan, and Kirupha, SD., "Thermodynamic and Kinetics Studies of Cadmium Adsorption from Aqueous Solution onto Rice Husk Braz”. J. Chem. Eng. Vol. 27 No. 2. 2010.

[9] Malakootain, et al. "Fluoride Removal from Aqueous Solution by Pumice. African J. of Environ. Science and Tehnology. Vol. 5(4). 299-306. 2011.

[10] Zohre, Shahryari, Ataalah Soltani, Mehdi Azadi. "Experimet tStudy on Methylene Blue Adsorption from Aquoeus Solution onto Carbon Nano Tubes". Inter. J. of Water and Environ. Eng. Vol. 2(2). 016-026. 2010.

[11] Rusdianasari, S. Arita, E. Ibrahim, Ngudiantoro. "Treatment of Coal Stockpile Wastewater by Electrocoagulation using Aluminum Electrodes". J. Adv. Material Sci. Vol 896. 145-148. 2014.

[12] Carneiro, P.A, et al. "A comparative on Chemical and Electrochemical Degradation of Reactive Blue 4 Dye". Portugaliae Electrochimica Acta (21). 49-67. 2003. 